Нурмухаметов Руслан Наилевич

аспирант кафедры уголовного права

и процесса Института права

Башкирского государственного университета

\section{К ВОПРОСУ О ПРЕДМЕТЕ И ПРЕДЕЛАХ ДОКАЗЫВАНИЯ В АПЕЛЛЯЦИОННОМ ПРОИЗВОДСТВЕ ПО УГОЛОВНЫМ ДЕЛАМ}

Аннотация:

В процессе рассмотрения уголовного дела суд апелляционной инстанции прибегает к доказыванию. Следовательно, закономерно возникновение вопроса о самостоятельном значении предмета доказывания в суде апелляционной инстанции, а также определения его специфики. Учитывая специфику апелляционного производства, необходимо определить особенности не только у предмета, но и у пределов доказывания. Автор приходит к выводу о том, что под ипредметом доказывания в апелляционном производстве» следует понимать совокупность связанных с проверкой приговора фактических обстоятельств, оснований, доводов и аргументов, определяемых содержанием апелля ционных жалоб (представлений) и возражений на них и требующих непосредственного исследования доказательств и доказывания в суде апелляционной инстанции. Под "пределами доказывания в апелляционном производстве» следует понимать совокупность исследованных судом апелляционной инстанции доказательств, содержание, качество и количество которых позволяют ответить на заявленные в жалобе (представлении) доводы, проверить законность, обоснованность справедливость обжалуемого судебного решения и вынести законное и обоснованное решение по делу.

Ключевые слова:

уголовно-процессуальное право, апелляционное производство, предмет доказывания, пределы доказывания, новые доказательства, жалоба, фактические обстоятельства, предмет проверки.
Nurmukhametov Ruslan Nailevich

PhD student, Criminal Law and Procedure Department, Institute of Law, Bashkir State University

ON THE ISSUE OF PROVING SUBJECT AND LIMITS IN APPEAL PROCEEDINGS IN CRIMINAL CASES

\begin{abstract}
Summary:
The appeals court conducts proving in the process of considering criminal cases. This raises the question of the independent significance of the subject relevant to proof in the appeals court, as well as the determination of its specificity. Taking into account the specificity of the appeal proceedings, it is necessary to determine the features not only of the subject, but also of the limits of the appeal proving. The author therefore concludes that the "subject of appeal proving" should beunderstood as a combination of factual circumstances, grounds and arguments, related to the reviewing of sentences, determined by the content of appeals and objections and requiring direct investigation of evidence in the appeals court. The term "limits of appeal proving" should be understood as the totality of the evidence examined by the appeals court, the content, quality and quantity of which allow to answer the case presented in the complaint, to check the legality, justifiability and fairness of the appealed judicial decision, and to make a legal and informed decision in the case.
\end{abstract}

Keywords: criminal procedural law, appeal proceedings, proving subject, proving limits, new evidence, complaint, factual circumstances, subject to verification.

Уголовно-процессуальный кодекс Российской Федерации (далее - УПК РФ) [1] предусматривает право апелляционного обжалования не вступивших в законную силу решений суда первой инстанции. Апелляционное производство по уголовным делам представляет собой форму проверки не вступивших в законную силу решений суда первой инстанции, единственной инстанции, имеющей право проверить судебное решение по фрактическим и правовым основаниям. Именно поэтому мы считаем, что актуальным является анализ предмета доказывания в суде апелляционной инстанции, а также определение его специфики.

В рамках апелляционного пересмотра уголовного дела следует различать процесс доказывания, когда стороны оспаривают непосредственно фрактические обстоятельства по делу от процесса обоснования судом апелляционной инстанции собственного решения, когда оспариваются не сами фрактические обстоятельства по делу, а проверяется то, как их оценил суд первой инстанции; само решение.

Предмет доказывания в апелляционной инстанции напрямую зависит от того, по каким основаниям подается жалоба (представление). Указанных оснований проверки может быть множество, следовательно, сформулировать единый предмет доказывания в суде апелляционной инстанции невозможно, потому что он будет индивидуален в зависимости от особенностей рассматриваемого уголовного дела. 
Закрепленные в статье 73 УПК РФ обстоятельства при пересмотре уголовного дела в апелляционном порядке могут устанавливаться фрагментарно. По мнению некоторых авторов, статья 73 УПК РФ не содержит исчерпывающего перечня обстоятельств, возникающих в суде апелляционной инстанции [2, с. 28]. Мы полагаем, что в суде апелляционной инстанции предмет доказывания находится в подчиненном положении у предмета проверки.

Таким образом, мы считаем, что под «предметом доказывания в апелляционном производстве» следует понимать совокупность связанных с проверкой приговора фрактических обстоятельств, оснований, доводов и аргументов, определяемых содержанием апелляционных жалоб (представлений) и возражений на них и требующих непосредственного исследования доказательств и доказывания в суде апелляционной инстанции.

Предметом доказывания в апелляционном производстве могут стать обстоятельства, закрепленные в статье 73 УПК РФ. В случаях, когда оспариваются фрактические обстоятельства, суд апелляционной инстанции осуществляет доказывание, которое будет оказывать помощь в выявлении и исправлении ошибок. Суд апелляционной инстанции собирает, проверяет и оценивает доказательства для того, чтобы устранить нарушения, противоречия, неполноту в выводах суда первой инстанции о фактических обстоятельствах уголовного дела, причем, в соответствии с частью 6 статьи 389.13 УПК РФ, судом могут быть исследованы как имеющиеся в уголовном деле доказательства, так и новые доказательства.

В качестве предмета доказывания в суде апелляционной инстанции могут выступать фактические обстоятельства, не связанные с закрепленным в статье 73 УПК РФ предметом доказывания по уголовному делу, однако оказывающие существенное влияние на вынесенное судом первой инстанции решение и входящие в предмет проверки.

В качестве примера можно привести случаи, когда имело место нарушение тайны совещания коллегии присяжных заседателей при вынесении вердикта. В таком случае может потребоваться допрос присяжных заседателей либо исследование доказательств с целью выявления нарушения тайны совещания.

Приведем пример из судебной практики. Осужденный М. обжалует приговор суда, так как, по его мнению, была нарушена тайна совещания коллегии присяжных заседателей, потому что во время совещания к ним вошел судебный пристав и пригласил их в зал, однако было установлено, что присяжные заседатели не были готовы к оглашению вердикта. Суд апелляционной инстанции допросил присяжных, судебного пристава, а также с учетом информации, зафиксированной аудиозаписью, пришел к выводу о том, что судебный пристав не присутствовал при совещании присяжных заседателей, следовательно, указанное обстоятельство не может расцениваться как нарушение положений части 2 статьи 341 УПК РФ, приговор был оставлен без изменения, а апелляционная жалоба - без удовлетворения [3].

Примером может служить изученное нами уголовное дело: потерпевший обратился с жалобой на приговор, так как дело было рассмотрено в его отсутствие, вследствие чего он был лишен возможности участвовать на заседании суда. Суд апелляционной инстанции непосредственно исследовал материалы уголовного дела и установил, что имеющаяся в деле телефонограмма, в которой потерпевший просит суд рассмотреть уголовное дело в его отсутствие, отменяется предоставленным потерпевшим заявлением о невозможности прибыть в суд по состоянию здоровья в конкретную дату и другими документами. Суд направил уголовное дело на новое рассмотрение [4].

Анализ специальной литературы позволяет нам говорить о том, что в науке нет единого мнения относительно определения пределов доказывания в апелляционном производстве. Одни авторы ввиду прочной связи предмета и пределов доказывания отождествляют данные понятия [5, с. 227-228], другие считают, что пределы доказывания представляют собой «совокупность информации, которая привлекается следователем или судом в доказательственную деятельность для обоснования выводов по делу» [6, с. 89]. Зотов Д.В. предлагает рассматривать пределы доказывания в качестве «достаточного числа источников доказательств, требуемого для обоснования процессуального решения» [7, с. 65]. С.А. Шейфер определяет пределы доказывания как «границы познавательной деятельности следователя и суда, определяемые моментом, когда цель доказывания оказывается достигнутой, т.е. когда с необходимой степенью надежности (вероятно либо достоверно) установлены подлежащие доказыванию обстоятельства. В этот момент доказывание прекращается, ибо необходимость в нем отпадает» [8, с. 86]. Мы согласны с мнением авторов, считающих, что пределы доказывания представляют собой достаточную и индивидуальную по каждому уголовному делу совокупность доказательств, которой достаточно для разрешения уголовного дела по существу [9, с. 4].

Учитывая то, что апелляционный порядок производства по уголовным делам обладает собственным специфическим предметом доказывания, определение которому нами было дано ранее, пределы доказывания в апелляционном производстве по уголовным делам будут сформированы, и доказательств будет достаточно тогда, когда будут устранены неполнота в установлении обжалуемых заявителем фактических обстоятельств по уголовному делу. 
Пределы доказывания могут быть шире в тех случаях, когда судом апелляционной инстанции происходит расширение судебного следствия в сравнении с тем, которое проводилось первой инстанцией. Пределы доказывания расширяются за счет того, что производилось исследование новых доказательств.

Для иллюстрации приведем пример из судебной практики. Потерпевший, являясь индивидуальным предпринимателем, определил размер причиненного преступлением ущерба, исходя из стоимости товаров на момент их реализации в размере трехсот семидесяти пяти тысяч рублей. Суд апелляционной инстанции с целью установления реальной стоимости похищенного имущества назначил судебную товароведческую экспертизу, результатом которой явилось установление рыночной стоимости с учетом износа имущества в размере двухсот семи тысяч рублей. Таким образом, проведение экспертизы с целью уточнения фактических обстоятельств, которые влияют на квалификацию преступления и размер наказания, осуществили расширение пределов доказывания в сравнении с совокупностью доказательств, собранных в суде первой инстанции [10].

Пределы доказывания в апелляционном производстве могут быть уже, чем пределы доказывания в суде первой инстанции. В тех случаях, когда судом апелляционной инстанции проводится исследование и конкретизация фактических обстоятельств в обжалуемой заявителем части, никакие новые доказательства не исследуются, происходит сужение пределов доказывания.

В качестве примера рассмотрим материалы судебной практики. Суд первой инстанции установил, что М.Г. совершил присвоение специальной техники - прибора ночного видения. Защитник в апелляционной жалобе просит об отмене приговора суда. Суд апелляционной инстанции проанализировал показания свидетелей обвинения, письменные материалы уголовного дела и установил, что М.Г. не являлся материально-ответственным лицом, указанный прибор ему не передавался во владение. Каких-либо доказательств того, что именно осужденный М.Г. получил прибор ночного видения и присвоил его, суду не представлено. Об обстоятельствах проведения инвентаризации свидетели обвинения дали непоследовательные, противоречивые показания. Исследованный судебной коллегией телефонный разговор между М.Г. и его руководством опровергает все доказательства стороны обвинения, как показания свидетелей обвинения, так и письменные материалы, о причастности и виновности М.Г. в совершении преступления. Таким образом, судом апелляционной инстанции достоверно установлено, что отсутствие прибора на складе не связано с действиями М.Г. Приговор суда первой инстанции был отменен, уголовное дело прекращено в связи с непричастностью М.Г. к совершенному преступлению [11]. В данном случае судом апелляционной инстанции не проводилось исследование новых доказательств, было произведено уточнение фактических обстоятельств.

Таким образом, по нашему мнению, под «пределами доказывания в апелляционном производстве» следует понимать совокупность исследованных судом апелляционной инстанции доказательств, содержание, качество и количество которых позволяют ответить на заявленные в жалобе (представлении) доводы, проверить законность, обоснованность и справедливость обжалуемого судебного решения и вынести законное и обоснованное решение по делу.

\section{Ссылки:}

1. Уголовно-процессуальный кодекс Российской Федерации от 18 декабря 2001 г. № 174-Ф3 (с посл. изм. и доп. от 18 февраля 2020 г. № 25-Ф3) // Собрание законодательства Российской Федерации. 2001. № 52, ст. 4921.

2. Ярцев Р.В., Святкин А.М. Критерии доказанности // Мировой судья. 2017. № 7. С. 27-31.

3. Апелляционное определение Верховного Суда Российской Федерации от 27 ноября 2018 г. [Электронный ресурс] // Судебные и нормативные акты РФ. URL: https://sudact.ru/vsrf/doc/i80CXDoShJHg/ (дата обращения: 10.03.2020).

4. Апелляционное определение Калужского областного суда от 15 февраля 2017 г. [Электронный ресурс] // Судебные и нормативные акты РФ. URL: https://sudact.ru/regular/doc/ehnXISbYsr5X/ (дата обращения: 10.03.2020).

5. Фойницкий И.Я. Курс уголовного судопроизводства. Т. 1. 4-е изд. СПб., 1912. 567 с. [Электронный ресурс] // Сервис электронных книг «ЛитРес». URL: https://www.litres.ru/i-foynickiy/kurs-ugolovnogo-sudoproizvodstva-tom-i/ (дата обращения: 22.03.2019)

6. Барабаш А.С. Сущность уголовного процесса и его роль в формировании ответственности правонарушителя. Красноярск, 1997. 130 с.

7. Зотов Д.В. Пределы доказывания в уголовном процессе: формально-количественное исследование // Вестник Самарского государственного университета. 2014. № 11-2 (122). С. 59-66.

8. Шейфер C.А. Доказательства и доказывание по уголовным делам: проблемы теории и правового регулирования. M., 2008. 238 c.

9. Анпилогова Т.С. Соотношение пределов доказывания на стадиях предварительного расследования и судебного разбирательства // Российский следователь. 2019. № 2 С. 3-5.

10. Апелляционное постановление Судебной коллегии по уголовным делам Верховного Суда Республики Татарстан от 18 сентября 2018 г. // Судебные и нормативные акты РФ. [Электронный ресурc]. URL: https:// https://sudact.ru/regular/doc/qGU6K4Tjfz1/ (дата обращения: 10.03.2020).

11. Апелляционное определение Судебной коллегии по уголовным делам Московского городского суда от 14 декабря 2017 г. [Электронный ресурс]. Доступ из справ.-правовой системы «КонсультантПлюс».

Редактор: Мамлиева Лилия Нурихановна Переводчик: Мельников Евгений Вячеславович 